\title{
DANGER ZONE IN MANDIBULAR MOLARS BEFORE INSTRUMENTATION: AN IN VITRO STUDY
}

\section{ZONA DE RISCO EM MOLARES INFERIORES PREVIAMENTE A INSTRUMENTAÇÃO: ESTUDO "IN VITRO"}

\author{
Paulo Ferreira GARCIA FILHO, DDS, MS, PhD \\ Department of Endodontics, Federal University of Rio de Janeiro (UFRJ). \\ Ariadne LETRA, DDS, MS \\ Department of Endodontics, Fluminense Federal University (UFF). \\ Renato MENEZES, DDS, MS \\ Department of Endodontics (Post Graduation), Gama Filho University (UGF). \\ Antônio Márcio Rezende do CARMO, DDS, MS, PhD \\ Department of Endodontics, Federal University of Juiz de Fora (UFJF).
}

\begin{abstract}
7 he aim of this work was to measure the danger zone in mandibular molars, relating to strip perforations that might affect the mesial root during canal instrumentation.

One hundred mesial roots were sectioned $2 \mathrm{~mm}$ below the furcation and the distal concavities were measured with a microscope from the border of the canals to the outer dentin of the root. The average thickness of the danger zone of the mesial roots was $0.789+/-0.182 \mathrm{~mm}$. No significant statistical differences were observed comparing the danger zone of mesiobuccal and mesiolingual canals.
\end{abstract}

UNITERMS: Danger zone; Safety zone; Mandibular molars.

\section{INTRODUCTION}

Danger zone refers to the distal area in the mesial root in mandibular molars. Usually a straight layer of dentin, it becomes a preferable site for strip perforation during instrumentation (Figure 1). Safety zone, on the other hand, is described as the mesial area of the root, with a thicker layer of dentin, slightly touched by the endodontic instruments.

Recent instrumentation techniques emphasize a progressive crown-down preparation of the root canal using NiTi rotary instruments, enhancing cleaning, improving identification of the foramen and facilitating the obturation process. Preenlargement of the coronal and mid-third aspect of the root canal system increases tactile control when directing small, precurved negotiating files into the delicate apical third microanatomy ${ }^{1}$.

Abou-Rass, Frank, Glick ${ }^{1}$ first described the danger zone and safety zone of the mandibular molars, showing their importance during cleaning and shaping procedures

Sinai $^{9}$ observed that strip perforations in the cervical third of the root canal lead to inflammatory problems and subsequent breakdown of the supporting structures.

Dental literature studying the thickness of the dentin present in the danger and safety zones of mandibular molars is scarce, and most agree that canal instrumentation becomes somewhat difficult since transportation of the canal always occurs towards those areas during preparation of the cervical third of the canal ${ }^{2,7}$.

\section{MATERIAL AND METHODS}

Two hundred mesial canals from one-hundred mandibular molars extracted for several reasons were used in this study. All teeth should have complete root formation and diverging roots. Sex and age of the patients were not regarded as relevant. Carborundum disks were used to 
remove the dental crowns and distal roots. The circumferences around the mesial roots were marked at $2 \mathrm{~mm}$ from the furcation. Mesial roots were marked at $2 \mathrm{~mm}$ below the furcation, embedded in clear casting resin and horizontally cut. An optical microscope at $10 \mathrm{X}$ magnification and precision to the nearest $0.001 \mathrm{~mm}(1 \mathrm{u})$ was used to measure the danger zone of the mesial roots as follows: a point $A_{1}$ was chosen on the border of the mesiobuccal canal $(\mathrm{MB})$ and another point $\mathrm{B}_{1}$ on the border of the mesiolingual canal (ML). Two other points $A_{2}$ and $B_{2}$ were chosen in a straight line at the outer side of the root (Figure 2).

The distances between $\mathrm{A}_{1}$ and $\mathrm{A}_{2}$ and $\mathrm{B}_{1}$ and $\mathrm{B}_{2}$ were recorded as the danger zone of the mesiobuccal and mesiolingual canals, respectively.

\section{RESULTS}

The average thickness for the danger zones of the mesial roots was $0.789+/-0.182 \mathrm{~mm}$.

Statistical analysis (ANOVA and Tukey-Kramer) was conducted and showed no significant differences regarding the danger zone in the mesial root of mandibular molars.

\section{DISCUSSION}

Cleaning and shaping procedures must disinfect the root canal system and provide an adequate form to fit the obturation material ${ }^{3}$. Most instrumentation techniques adopt a flare preparation of the cervical third. However, excessive flaring might lead to undesirable episodes as transportation of the preparation into the danger zone, or even strip perforations of the root.

Kesseler, Peters, Lorton ${ }^{5}$, reported a mean value of 1.119 $+/-0.273 \mathrm{~mm}$ for the danger zone of 20 mandibular molars.

Lim, Stock ${ }^{6}$, studied the risks of perforation in mandibular molars and found danger zones with an average size of $1.05+/-0.33 \mathrm{~mm}$ in the MB canal and $1.05+/$ $0.24 \mathrm{~mm}$ in the ML canal, with a mean size of $1.05+/$ $0.28 \mathrm{~mm}$.

Berutti, Feldon ${ }^{2}$ used 15 mandibular molars and found an average of $1.19 \mathrm{~mm}$ for the $\mathrm{MB}$ danger zone and $1.25 \mathrm{~mm}$ for the ML.

Montgomery ${ }^{9}$ studied the danger zones of mandibular molars after biomechanical preparation, finding an approximate value of $0.976+/-0.24 \mathrm{~mm}$.

Meister, et al. ${ }^{8}$ reported that excessive flaring of curved canals represents a potential danger as the occurrence of strip perforations will end up in alveolar bone loss. Nevertheless, this study was published in 1979 and instruments used back then were not as developed as the ones available today. Modern instruments are capable to provide flaring with less canals transportation. New flute designs provide less "clogging" of smear layer.

Recent studies with instruments of differentiated designs have described that no differences can be observed in terms of danger zones in simulated canals ${ }^{3}$. However, Bryant, et al. ${ }^{4}$ have found the creation of danger zones and perforations $(5 \%)$ using Profile rotary instruments in simulated canals.

This study used 200 mesial canals of mandibular molars with an average size of $0.791+/-0.187 \mathrm{~mm}$ and $0.88+/-$ $0.78 \mathrm{~mm}$ for each mesiobuccal and mesiolingual canals. The mean size for the 200 canals used was $0.789+/-0.182 \mathrm{~mm}$.

A similar study by McCann, Keller, La Baunty ${ }^{7}$, found an average $0.8+/-0.2 \mathrm{~mm}$ as the size of the danger zone in 20 molars and $0.7+/-0.1 \mathrm{~mm}$ for another 20 molars. The mean size was $0.75+/-0.15 \mathrm{~mm}$. These same authors reported an average dentin loss of $0.448+/-0.04 \mathrm{~mm}$ in the distal concavity after instrumentation. From this point of view, the distal walls of the roots used in this study, with $89.5 \%$ measuring 0.5 to $1 \mathrm{~mm}$, would be reduced to a critical point after canal instrumentation.

Lim, Stock ${ }^{6}$ reported the relationship between the size of the distal walls and vertical root fracture. The smaller the size, the greater the susceptibility for root fractures. Our study showed $13 \%$ distal concavities measuring 0.5 $0.59 \mathrm{~mm}, 2 \%$ measuring $0.4-0.49 \mathrm{~mm}$ and $0.5 \%$ measuring $0.3-0.39 \mathrm{~mm}$, which, according to these authors, would be more susceptible to vertical fractures.

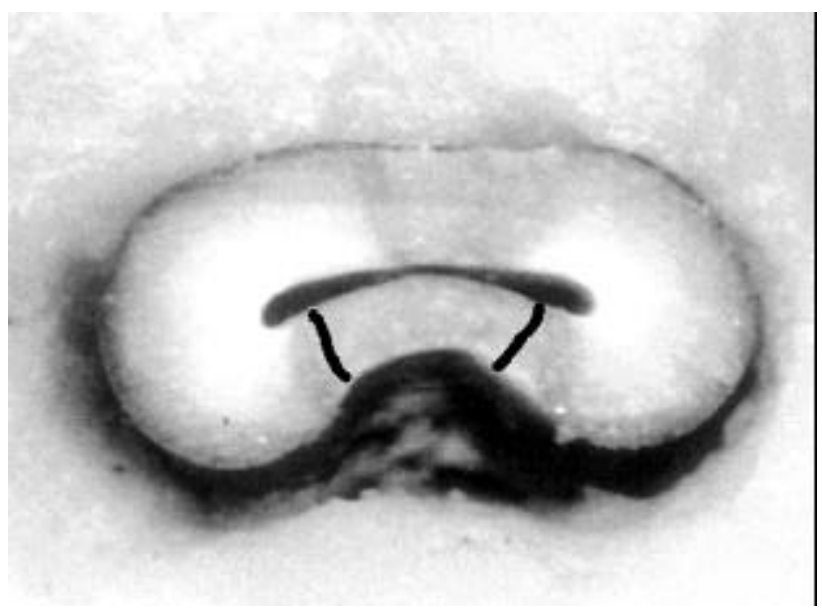

FIGURE 1- Danger zone in the mesial roots of mandibular molars

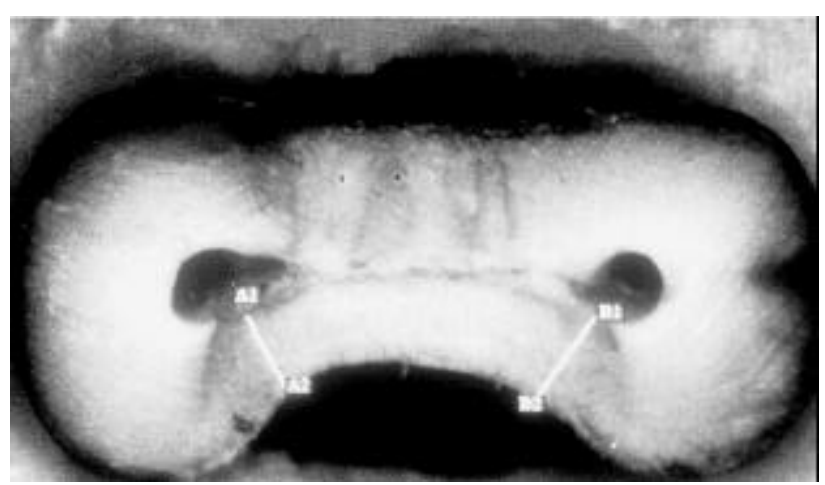

FIGURE 2- Reference points to measure the danger zone of each mesial canal 


\section{CONCLUSIONS}

There was no significant statistical difference between the danger zone in MB and ML canals of mandibular molars. However, professionals must be acquainted with the sizes of the mesial roots of mandibular molars, in order to use appropriate instruments and avoid procedural accidents as strip perforations.

\section{RESUMO}

O objetivo deste estudo foi medir as zonas de risco de raízes mesiais de molares inferiores, demonstrando porque perfurações radiculares podem ocorrer durante o preparo do sistema de canais radiculares. Cem raízes mesiais de molares inferiores foram seccionadas horizontalmente $2 \mathrm{~mm}$ abaixo da bifurcação e as concavidades distais foram medidas com o auxílio de um microscópio, desde a borda dos canais até a superfície externa da raiz. A espessura média para as zonas de risco das raízes mesiais foi 0,789 +/- 0,182 $\mathrm{mm}$. Não houve diferença estatística significante entre as medidas das zonas de risco nos canais mésio-vestibulares e mésio-linguais de molares inferiores.

UNITERMOS: Zona de risco; Zona de segurança; Molares inferiores.

\section{REFERENCES}

1- Abou-Rass M, Frank AL, Glick DH. The anticurvature filing method to prepare the curved root canal. J Amer Dent Assoc 1980;101: 792-4.

2- Berutti L, Feldon G. Thickness of cementum/dentin in mesial root of mandibular first molars. J Endod 1992;18: 545 -8.

3- Bishop K, Dummer PM. A comparison of stainless steel Flexofiles and nickel-titanium Nitiflex files during the shaping of simulated canals. Int Endod J 1997; 30: 25-34.

4- Bryant ST, Dummer PM, Pitoni C, Bourba M, Moghal S. Shaping ability of .04 and .06 taper Profile rotary nickel-titanium instruments in simulated root canals. Int Endod 1999; 32: 15564.

3- Cohen S, Burns R. Pathways of the Pulp. $8^{\text {th }}$ Ed. Cleaning and Shaping the Root Canal System: Chapter 8, 246. Mosby, St. Louis, 2000 .

5- Kessler JR, Peters DD, Lorton L. Comparison of the relative risk of molar root perforation using various endodontic instrumentation techniques. J Endod 1983; 9: 439 -77.

6- Lim SS, Stock CJR. The risk of perforation in the curved canal: anticurvature filing compared with step-back technique. Int Endod J 1987; 20: 33 -9.
7- Mc Cann JT, Keller DL, La Baunty GL. Remaining dentin / cementum thickness after hand and ultrasonic instrumentation. J Endod 1990;16:109-13.

8- Meister F, Tennyson JL, Gerstein H, Davies EE. Endodontic perforation which resulted in alveolar bone loss. Oral Surgery 1979;47: 463-70.

9- Montgomery S. Root canal wall thickness of mandibular molar after biomechanical preparation. Journal of Endodontics 1985;1: 257-63.

10- Sinai IH Endodontic perforation: their prognosis and treatment. J Amer Dent Assoc 1977;95: 90-5.

Recebido para publicação em: 10/06/2003

Enviado para reformulações em: 06/08/2003

Pronto para publicação em: 19/08/2003

Correspondence:

Renato Menezes

Rua Amadeu Gomes, Cond. Ubá V, Rua 3, Quadra 5 , Casa 10

Pendotiba

Niterói, 24320-010, RJ, Brasil.

E mail: menezesr@uol.com.br 